\title{
Geochemical behavior of heavy metals in differents environments in Rodrigo de Freitas lagoon - RJ/Brazil
}

\author{
ESTEFAN M. FONSECA ${ }^{1}$, JOSÉ A. BAPTISTA NETO ${ }^{1}$, MARCOS A. FERNANDEZ ${ }^{2}$, \\ JOHN MCALISTER ${ }^{3}$ and BERNARD SMITH ${ }^{3}$ \\ ${ }^{1}$ Laboratório de Geologia e Geofísica Marinha/LAGEMAR, Universidade Federal Fluminense \\ Av. Litorânea s/n, Gragoatá, 24210-340 Niterói, RJ, Brasil \\ ${ }^{2}$ Faculdade de Oceanografia, Universidade do Estado do Rio de Janeiro \\ Rua São Francisco Xavier, 524, Maracanã, 20550-013 Rio de Janeiro, RJ, Brasil \\ ${ }^{3}$ School of Geography, Archaeology and Palaeoecology, Queen's University Belfast \\ Belfast, Northern Ireland, BT7 1NN, United Kingdom \\ Manuscript received on November 4, 2009; accepted for publication on October 28, 2010
}

\begin{abstract}
The accelerated urbanisation without a planning, brought several environmental problems to Rio de Janeiro coastal zone, especially in areas such as Rodrigo de Freitas lagoon, which receives a great amount of untreated sewage every day. To assess the nature, potentially sources and extent of heavy metal pollution in the lagoon, sediments from the surrounding streets, from the entrance of the main canal that drains to the lagoon and from the bottom of the lagoon were collected and analysed by a modified selective extraction procedure in order to study the geochemical partitioning and bioavailability of $\mathrm{Zn}, \mathrm{Cu}, \mathrm{Cr}, \mathrm{Ni}$ and $\mathrm{Pb}$ in these three compartments. The present study verified an increase in the $\mathrm{Cu}, \mathrm{Pb}$ and $\mathrm{Zn}$ concentrations in the north of the Rodrigo de Freitas lagoon. Despite the different levels of oxidation between the sediments accumulated in the streets and in the bottom of the lagoon, the geochemical partitioning of the heavy metals did not show any pattern of variation for the metals, except for the element $\mathrm{Cu}$. No concentrations were found in the soluble phase of samples collected in the surfacial sediments of the lagoon, suggesting no bioavailability of heavy metals.
\end{abstract}

Key words: heavy metals, Rodrigo de Freitas lagoon, sediments.

\section{INTRODUCTION}

Originated primarily in the continental crust, soil, sediments and urban dust constitute effective deposits of pollutants. The urban runoff sediments can be considered as a bigger influence factor on the human health in urban centers (Yongming et al. 2006). Although the great number of references regarding to the contamination of the urban sediments and dust, very little information on this subject is available referring to the developing countries (Banerjee 2003).

Correspondence to: Estefan Monteiro da Fonseca

E-mail: oceano25@hotmail.com
According to McAlister et al. (2005), urban runoff sediments accumulations throughout paved streets in urbanised areas represents important deposits of urban contaminated sediment, especially for heavy metals (Förstner and Wittmann 1983, McAlister et al. 2005), being able to reflect beyond the geologic conditions and the local environment quality.

In terms of toxicity and risk for the public health, heavy metals are frequently cited in studies dealing with deposited sediments in avenues of automotive transport (Olivero and Solano 1998). Heavy metals such as copper, lead and zinc are of particular interest in the studies 
on urban discharges due to their toxic character for the aquatic organisms and persistence in the environment (Hoffman et al. 1984, Borchardt and Sperling 1997, Walker et al. 1999, Brown and Peake 2006).

The main sources of contaminants for the streets also include the atmospheric dust, the degradation of automobiles parts and the fossils fuel burning (Sansalone and Glenn 2002, Pereira et al. 2007). Emissions of the motorized vehicles, drippings of the oil of the crankcase, degradation of the tires of vehicles and surfaces of roads are all diffuse sources of chemical contaminants in urban environments (Brown and Peake 2006). During the rainy periods, these contaminants are washed off the roofs, the traffic roads and other surfaces and, thus, can be carried by the collecting pluvial water canals for the adjacent water bodies. Mungur et al. 1995, and Shinya et al. 2000, suggest that the road runoff can contribute with up to $50 \%$ of solids in suspension, $16 \%$ of the total of hydrocarbons, and 35 to $75 \%$ of the total heavy metals received by the coastal water bodies.

The study of the contaminants in sediments involving concentration informations and species allow the tracking of potential sources (Walker et al. 1999, Gonzalez et al. 2000, McCready et al. 2000, Soclo et al. 2000).

Traditionally, the presence of heavy metals in the particulate matter is characterized in terms of total concentrations, although the environment significance depends, among others factors, on its specific partition and its particular affinities with the matrices present in the environment (Manno et al. 2006). The same authors suggested the necessity to understand the way in which the elements react to the main physicochemical variations in the environment, in order to determine their geochemical dynamic.

Considering the peculiar characteristic of drastic changes in the water physicochemical parameters, and because of the fine sediments accumulations that result from the low current energy and the great amount of load pollutants, mainly organic matter, and the aggressions of the urbanization processes, coastal environments have become, throughout history, extremly vulnerable (Benoit et al. 1999).

According to Benoit et al. (1999), estuarine ecosystems such as coastal lagoons are particularly en- vironmentally complex due to their localization in the transitional zone, between the continent and the ocean, and their, main characteristic of semi-unclosed environments. Estuarine environments are characterized by high spatial fluctuations in the physicochemical parameters and by being constantly a target of anthropogenic impact, including the discharge of domestic and industrial sewage, which can modify their morphology and affect the quality of their water body. In this context, Rodrigo de Freitas coastal lagoon is located in a high urbanized area in the Rio de Janeiro city. Surrounded by several roads with a very intense daily automobiles traffic, this lagoon is influenced by several inputs of pollutants, including a high variety of heavy metals (D.D. Loureiro, unpublished data).

The aim of this work is to evaluate the levels of pollution in the Rodrigo de Freitas lagoon, and also to access the mains sources of its pollutants, throughout the analysis of the total concentrations and the partition of the heavy metals in order to understand the geochemical dynamics of heavy metals in several compartments of this ecosystem.

\section{STUDY SITE}

The Rodrigo de Freitas lagoon is located in the south region of Rio de Janeiro $\left(22^{\circ} 57^{\prime} 02^{\prime \prime} \mathrm{S}\right.$; $\left.043^{\circ} 11^{\prime} 09^{\prime \prime} \mathrm{W}\right)$ (Fig. 1). Its surface has an irregular polygon form, with an area of $2.5 \mathrm{~km}^{2}$, a perimeter with about $7.5 \mathrm{~km}$, and its bigger length reaches $3 \mathrm{~km}$ long (Barroso 1989). Its highest depths reach $11 \mathrm{~m}$ (Andreata et al. 1997). This lagoon is connected to the sea by a canal of the Jardim de Alah that separates the quarters of Ipanema and Leblon. The canal has a length of $835 \mathrm{~m}$, and it is frequently blocked by sand deposits. The dynamics of the renewal of the lagoon waters is very complex. The draining basin is composed of the Macacos River, which is the main input of fresh water, and the Cabeça and Rainha Rivers (Andreata et al. 1997).

The lagoon is surrounded by a highly urbanised area, which is responsible for a huge input of pollutants loads, not only from its main tributaries rivers, but also from the pluvial water galleries. Previous works allowed to identify in this lagoon, places where the total metal concentrations had exceeded the background levels (D.D. Loureiro, unpublished data). 

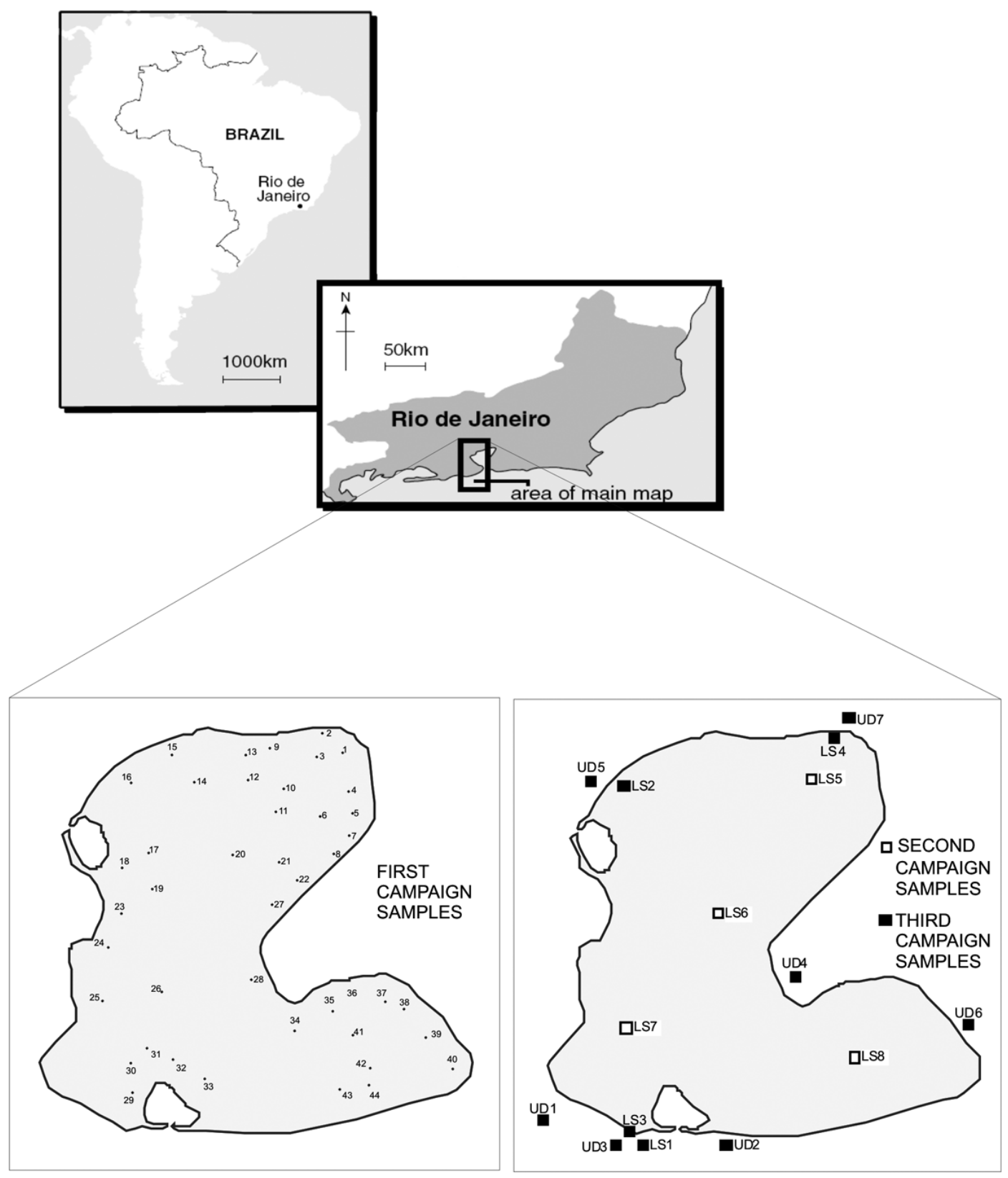

Fig. 1 - Localization of Rodrigo de Freitas lagoon and sampling stations.

On the other hand, from studies that have been carried out since the last three decades, it is possible to affirm that one of the factors that decreases the quality of this ecosystem is the stratification of water due to the restricted circulation and the water renewal (Rosman 1990). The deeper water layer soon becomes anaerobic and rich in sulfuric gas because of the oxidation of the organic matter in the bottom of the lagoon (Rosman 1990). Thus, one concludes that this environment presents favourable conditions for the accumulation of pollutants in its substratum.

\section{MATERIALS AND METHODS}

The present study used three approaches of sediments collection for the characterization of the heavy metal levels in the urban runoff sediments surrounding the lagoon and in its bottom: 
The first approach consisted of the sampling of 44 botton sediments from the lagoon with a Van Veen grab sampler that covered the whole lagoon (Fig. 1). The second approach was the sampling of the botton sediments of four stations. The anoxic conditions of the samples in the second campaign were kept thought by the isolation of the sample in the subaqueous environment, freezing, opening under atmosphere of $\mathrm{N}_{2}$ and liofilization in the lab.

The third approach aimed at the collection of the samples in the urban runoff sediments in the streets around the lagoon, where 7 samples were collected, and in the mouth of the main canals that drains to the lagoon, where 8 samples were collected (Fig. 1). In the second and in the third campaigns, the physical-chemical conditions of the aquatic environment was analysed through the measurement of the $\mathrm{pH}$, Eh and temperature in situ. The $\mathrm{pH}$ analysed was carried out through a pHmeter Metrohm 744. The Eh was measured with a platinum electrode (Analion), model ROX 673, calibrated with its proper standards.

The selective extraction analysis used both shaking and heating techniques (McAlister et al. 2003), in which a prepared sample of $0,500 \mathrm{~g}$ was weighed into acid washed polyproplene tubes, and blanks were prepared by taking each extractant without the sample through all the preparation procedures prior to analysis. Watersoluble ions were extracted using a modified version of the Buurman et al. 1996 technique where a smaller sample weight was extracted with a lower volume of deionised water $(2.5 \mathrm{ml})$, diluted to $10 \mathrm{ml}$ and membrane filtered $(0.2 \mu \mathrm{m})$ prior to analysis (McAlister et al. 2003). This extraction protocol was modified to include the organic phase, which was extracted using a 3:1 mixture of $\mathrm{HNO}_{3}$ and $\mathrm{HCl}$ (Lefort aqua regia) to ensure a better oxidation of the organic matter. Acid digestion of the residual phase was carried out using a Perkin Elmer microwave digestion system. Analytical grade chemicals were used and all solutions were prepared using Grade A glassware and deionised water. Elemental analyses were carried out using a Perkin Elmer Model 3100 atomic absorption spectrometer. The detection limit for $\mathrm{Cu}, \mathrm{Pb}, \mathrm{Zn}, \mathrm{Cr}$ and $\mathrm{Ni}$ was $0.05 \mathrm{ppm}$; $0.1 \mathrm{ppm} ; 0.01 \mathrm{ppm} ; 0.05 \mathrm{ppm}$ and $0.04 \mathrm{ppm}$, respectively.

\section{RESULTS AND DISCUSSIONS}

The Physical-Chemical Parameters

According to Warren and Haack (2001), the combination between parameters such as potential redox and $\mathrm{pH}$ can affect the behaviour of metals, influencing their solubility. The Eh value recorded in the station LS4 was the lowest one, reaching $-440 \mathrm{mV}$ and indicating the station LS4 as one of the most reduced stations. It was considered that this station is located closer to a pluvial source contaminated with organic loads, which can affect the physical-chemical parameters of the station water. In the other stations in the inner of the lagoon, the values ranged between -87 and $-305 \mathrm{mV}$, characterizing sufficiently reducing sediments at the time of the collection.

The $\mathrm{pH}$ has been pointed out as one of the most important physical-chemical parameters (Harter 1983, Basta and Tabatabai 1992a). Its variation can modify the load of surface of colloids, regulating, together with other attributes of the water, the magnitude of the adsorption of the metallic ions in the soil and sediments (Naidu et al. 1994). In low values of $\mathrm{pH}$, the hydrated forms of the metallic ions are favoured, while in high $\mathrm{pHs}$, a trend of the formation of a complex with hydroxiles and carbonates occur (Sposito 1989).

The recorded values of $\mathrm{pH}$ ranged between 7.51 and 8.38. The highest values were recorded in the stations LS1 and LS3. The average values found in the others stations was 7.56. The highest values were found near the canal that connected the lagoon with the ocean, which explains these values.

\section{Heavy Metal Total Concentrations}

According to Yongming et al. (2006), the components and the respective concentrations found in the urban dust, soils and sediments are important factors to be evaluated in the analyses of the environmental quality, especially in big cities. In the special case of the urban runoff sediments, the interest in the concentrations of pollutants associated with this dust increased significantly in the last decades, mainly concerning the concentrations and distribution of lead (Jones and McDonald 1983, Von Schirnding and Fuggle 1996, Chatterjee and Banerjee 1999), copper and zinc, as well as the identifi- 

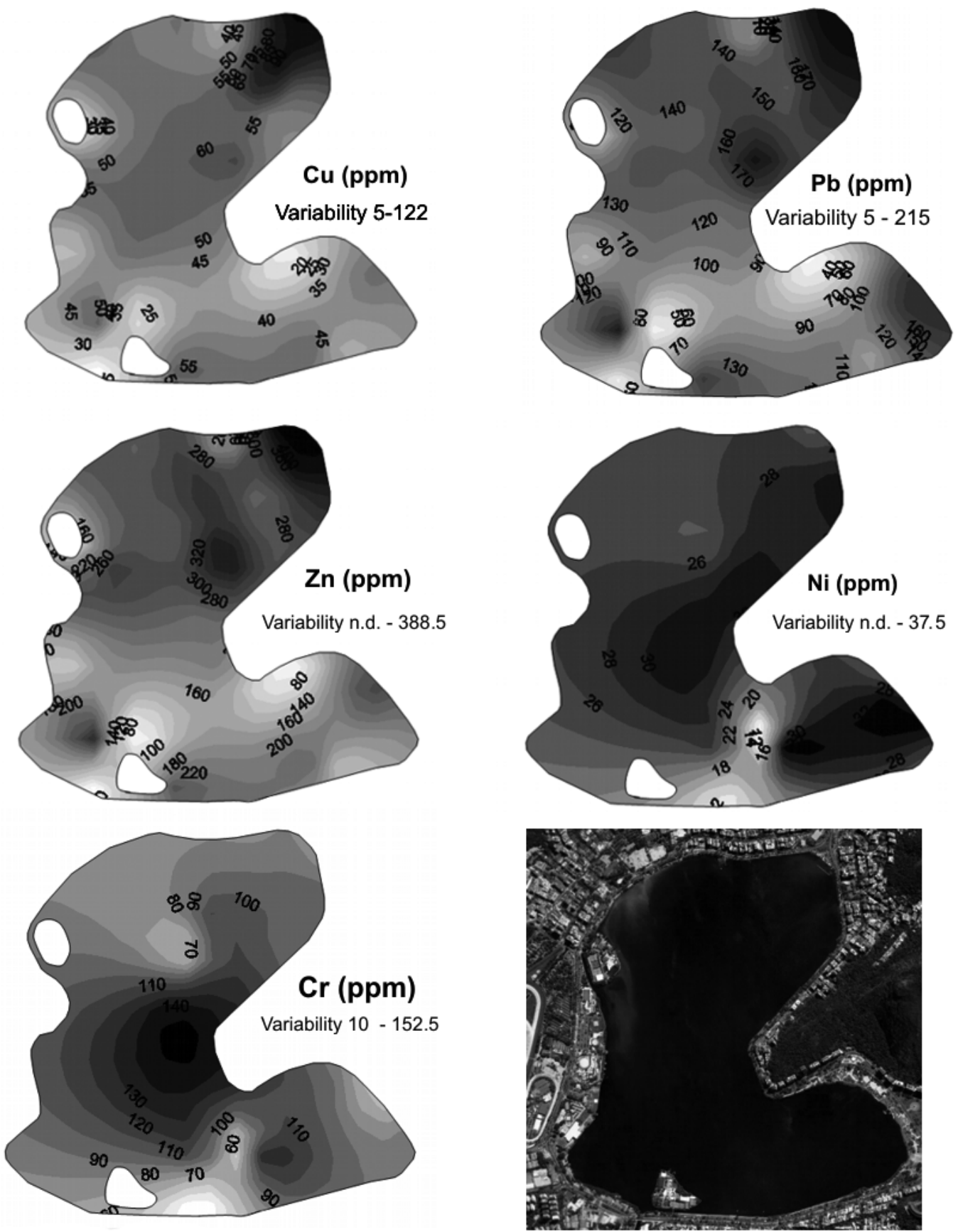

Fig. 2 - Heavy metal spatial variations during the first campaign.

cation of their sources (Fergunson and Kim 1991, Nagerotte and Day 1998). Urban soils, on the other hand, are not only deposits of pollution, but can also act as sources of pollution to the environment (Yongming et al. 2006).

The levels of the heavy metals concentrations found in the inner of the lagoon shows concentrations of $\mathrm{Cu}$ ranging from 5 to $122 \mathrm{ppm}$, with an average of 48.7ppm. In order to obtain the spatial distribution of the heavy metals concentrations in the bottom sediments of the lagoon, the data were plotted in the located map (Fig. 2) in this map it is possible to observe an increase in the concentration of the $\mathrm{Cu}$ in the north of the lagoon. D.D. Loureiro, unpublished data, in a similar study in the same lagoon, recorded slightly lower con- 
centrations of $\mathrm{Cu}$, ranging around $100 \mathrm{ppm}$. His method of extraction is based on the techniques described by Loring and Rantala (1991) and UNEP (1995). According to the methods of digestion, the decomposition of the sediment samples was induced under high temperatures and, when necessary, the pressure was used. The total digestion of his samples using $\mathrm{HNO}_{3}$ and $\mathrm{HCl}(3: 1)$ can explain the reason for the lower concentrations obtained in his study. Despite the higher aliquot of sediments used in his extraction $(1 \mathrm{~g})$ for his analyses, the method used in the present study had a more aggressive character of digestion. Benoit et al. (1999), used the same amount of sediment samples, $10 \mathrm{ml}$ a mixture of $\mathrm{HNO}_{3}$ and $\mathrm{HF}$ (50:50); in samples of the Hudson Bay, New York, they found concentrations of total $\mathrm{Cu}$ ranging around 50ppm, which is lower if compared with the present study.

Sediment cores were collected in Jurujuba Sound, Niterói, a city near Rio de Janeiro, by Baptista Neto et al. (2000). Using the same method of extraction of the present work, they had determined similar concentrations of background 5ppm. In the same sediment cores, the authors found maximum concentrations afterurbanization of $100 \mathrm{ppm}$, which is compatible with the results found in the present study.

The total concentrations of $\mathrm{Cu}$ in the street sediments of the urban runoff and in the sediments collected in the mouths of the rivers and in the Jardim de Alah canal were lower than the concentrations found in the sediments collected in the inner part of the Rodrigo de Freitas lagoon. In the sediments accumulated in the streets, the maximum concentrations recorded for $\mathrm{Cu}$ was $51 \mathrm{ppm}$. The average values for $\mathrm{Cu}$ in the urban runoff sediments collected in the streets around Rodrigo de Freitas lagoon were lower than the majority of values found in the literature for other urban centers (Table I). McAlister et al. (2005) found higher values in the same city and in streets with intense traffic, including heavier types of transport such as buses and trucks.

The concentrations of $\mathrm{Pb}$ found in the present study ranged from 5 to $215 \mathrm{ppm}$, with an average of $125.8 \mathrm{ppm}$. The highest values were found either in the urban runoff sediments and in the bottom sediments of the lagoon. According to Alloway (1990a) and M.A.P. Pierangeli, unpublished data, the surfacial soil tend to accumulate $\mathrm{Pb}$ that came from atmospheric depositions or indus- trial and agricultural sources due to its low solubility and strong absorption to the sediment.

D.D. Loureiro, unpublished data once again found lower concentrations in the bottom sediments of the lagoon (about 100ppm). According to the study carried out by Baptista Neto et al. (1999), the concentrations of the regional background are of the order of $25 \mathrm{ppm}$. The spatial distribution of the total concentrations of $\mathrm{Pb}$ in the Rodrigo de Freitas lagoon (Fig. 2) showed the same pattern of $\mathrm{Cu}$, with an enrichment through the north of the lagoon. In the rivers mouth and in the canal that link the lagoon to the sea, the concentrations were lower, with maximum value reaching only $41 \mathrm{ppm}$. After the partial or total prohibition of the tetraethyl, there was an addition in the gasoline in some countries and the concentration of the particulate $\mathrm{Pb}$ in the air of the urban areas decreased, but it did not solve the problem of the pollution by this metal. Other sources are responsible mainly for the atmospheric pollution, in the industrial zones, risking the health of the population (Cochran et al. 1998). In the case of the urban runoff sediments, as well as $\mathrm{Cu}$, the concentration was lower than the average found in the literature (Table I). McAlister et al. (2005) recorded levels three times higher in the same area of this study. However, according to Pereira et al. (2007), the time of the sediment residence in the streets is very limited, with a low capacity of record. The comparison among different studies must take this characteristic into consideration. In terms of urban environment, $\mathrm{Pb}$ should be considered due to its negative effect for the human health (Vanz et al. 2003).

The pattern distribution of the total concentration of $\mathrm{Zn}$ was similar to $\mathrm{Cu}$ and $\mathrm{Pb}$, with lower concentrations in the river mouth and in the Jardim de Alah canal. In these areas, the highest concentrations was $170.5 \mathrm{ppm}$, and the highest concentration found in this study was in the inner bottom sediments of the lagoon, with $388.5 \mathrm{ppm}$.

$\mathrm{Zn}$ showed the same distribution pattern of enrichment as $\mathrm{Cu}$ and $\mathrm{Pb}$, indicating the same source of pollution in the north of the lagoon (Fig. 2). These results were higher than the values found by D.D. Loureiro, unpublished data and Benoit et al. (1999), who found values around 76.9 and 90ppm, respectively.

In the urban runoff sediments collected around 
TABLE I

Average concentrations of heavy metals in urban dust around the world available in the literature.

\begin{tabular}{c|c|c|c|c|l|l}
\hline $\mathrm{Pb}$ & $\mathrm{Zn}$ & $\mathrm{Cu}$ & $\mathrm{Cr}$ & $\mathrm{Ni}$ & \multicolumn{1}{|c}{ Location } & \multicolumn{1}{c}{ Author } \\
\hline 127.52 & 305.71 & 32.78 & 44.91 & 66.07 & $\begin{array}{l}\text { Rio de Janeiro city, } \\
\text { south zone, Brazil }\end{array}$ & Present work \\
\hline 368.88 & 1284.05 & 290.61 & 97.3 & 73.07 & $\begin{array}{l}\text { Rio de Janeiro city, } \\
\text { south zone, Brazil }\end{array}$ & McAlister et al. 2005 \\
\hline 230.52 & 421.46 & 94.98 & 167.28 & - & Xi'na, China & Yongming et al. 2006 \\
\hline 160 & 120 & 30 & 31 & 24 & $\begin{array}{l}\text { Residential area, } \\
\text { Southeastern Michigan,US. }\end{array}$ & Murray et al. 2004 \\
\hline 93 & 130 & 32 & 27 & 16 & $\begin{array}{l}\text { Commercial area, } \\
\text { Southeastern, US. }\end{array}$ \\
\hline 262 & 253 & 74 & 11 & - & Naples urban region, Italy & Imperato et al. 2003 \\
\hline
\end{tabular}

the lagoon, the average concentrations of $\mathrm{Zn}$ was 305.71ppm. This result is comparable with the ones of other urban areas, such as Naples, in Italy (Imperato et al. 2003) and in the urban regions of Michigan, USA (Murray et al. 2004) (Table I). McAlister et al. (2005) also found concentrations higher in the center of Rio de Janeiro, with an average reaching $1284.05 \mathrm{ppm}$.

In Europe and in the USA, the studies about urban runoff sediments are highlighting mainly the dynamic of copper, lead and zinc (Charlesworth et al. 2003). There were a few studies about metals such as chromium and nickel (Yongming et al. 2006).

The concentrations of $\mathrm{Cr}$ recorded in this study show a higher average, in most of the samples, of the background found by Baptista Neto et al. (2000), which is $5 \mathrm{ppm}$. Cr does not show a pattern of variations between the lagoon sediments and the urban runoff sediments, where the concentrations range from 10 to $152.5 \mathrm{ppm}$, with an average of $83.9 \mathrm{ppm}$ (Fig. 3). The average concentrations of chromium in the urban runoff sediments of adjacent streets to the Rodrigo de Freitas lagoon were very similar to the average concentration observed in the literature (Table I). However, the concentrations of $\mathrm{Ni}$ showed a higher average, if compared with others studies (Table I). These ranged between n.d. and $37.5 \mathrm{ppm}$, with an average of $25.9 \mathrm{ppm}$ in all the study area. On the other hand, the average concentrations of this element in the urban runoff sediments was $44.91 \mathrm{ppm}$, which is lower than the one of the study carried out in Xi'na, China (Yongming et al.
2006). Baptista Neto et al. (2000) found concentrations levels around 5ppm in the same area of study, which can be considered a natural concentration.

\section{Heavy Metal Selective Extraction}

The selective extraction of $\mathrm{Cu}$ showed an extremely differentiated behaviour between the two first compartments (urban runoff sediments and the sediments collected in the mouths of the canals) and in the sediments collected in the interior of the lagoon. In the two first compartments, the reductive phase predominated, whereas in the latter, the oxidized fraction was predominant. The same behaviour was described by McAlister et al. (2005) in samples of urban runoff sediments accumulated in streets of high traffic conditions. According to Ross (1994), the adsorption of metals by organic substances is particularly important for $\mathrm{Cu}$ and $\mathrm{Pb}$. Guilherme and Anderson (1998) suggested that, despite of the high degree of selectivity of the organic matter with $\mathrm{Cu}$ is caused by the formation of internal sphere complexes, also known as specific absorption, the preservation of the organic matter is directly linked with the levels of dissolved oxygen, it is expected that this phase has a greater importance in anoxic environments, such as the sediments of the Rodrigo de Freitas lagoon. Studies on this subject show an increase in the bioavailability of $\mathrm{Cu}$ during the aeration of anoxic sediments (Alastuey et al. 1999, Marseille et al. 2000), which suggests the great importance of the dissolved $\mathrm{O}_{2}$ concentrations for the $\mathrm{Cu}$ speciation. In estuarine sediments 

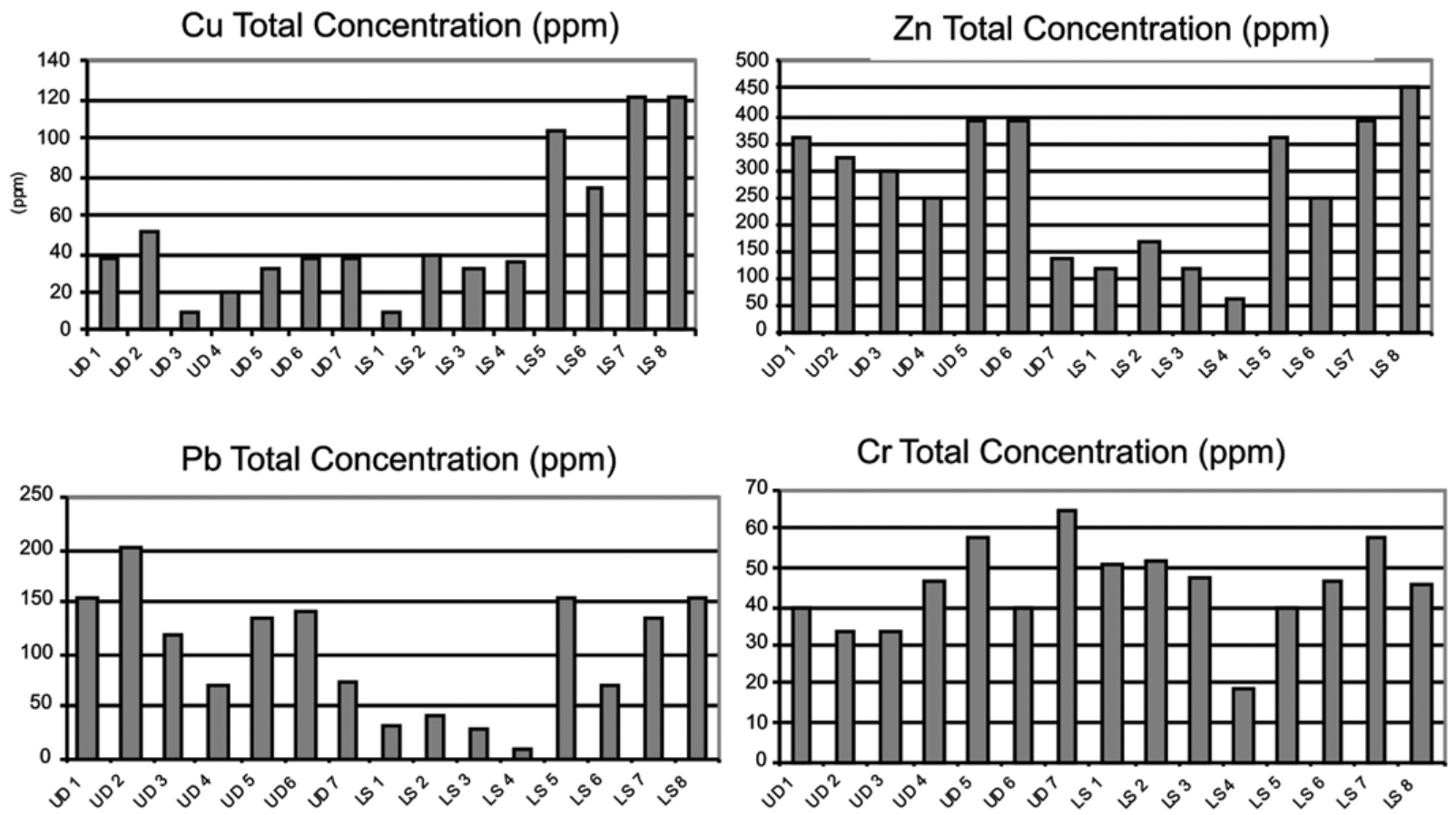

Ni Total Concentration (ppm)

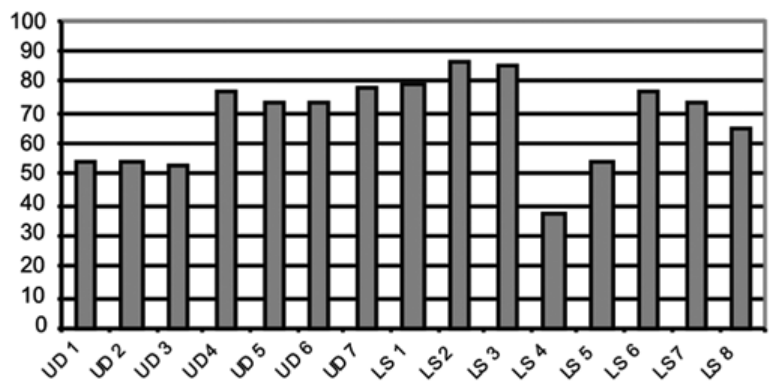

Fig. 3 - Heavy metal total concentration variation during the $2^{\text {nd }}$ and $3^{\text {rd }}$ campaigns.

from a tropical region, where the reductive and oxidable phases alternate, Ngiam and Lim (2001) recorded the same pattern of speciation. According to the same study, the levels of $\mathrm{O}_{2}$ were determinative in the percentage of each phase.

The $\mathrm{Cu}$ residual phase was only recorded in the interior of the lagoon, probably due to its high concentration in this area. In the other stations, the concentrations of $\mathrm{Cu}$ were below the detection limit. $\mathrm{Cu}$ was not recorded in the water soluble phase.

$\mathrm{Pb}$ presented a differentiated pattern at the entrance of the rivers and in the other compartments. The organic phase showed that the highest percentage was found at the entrance of the rivers, reaching up to
$100 \%$ in the station LS4. On the other hand, in the other stations the reductive phase was more important. In the urban runoff sediments accumulated in the streets of Rio de Janeiro, McAlister et al. (2005) recorded the same pattern of speciation, with the predominance of the reductive phase. The interchange between the organic and reductive phases was also verified by Ngiam and Lim (2001). Regarding the other phases, the carbonatic phase was extremely significant and predominated in some stations. In the stations located near the rivers entrances, however, the concentrations were below to the detention limit. Ngiam and Lim (2001) also commented on the great importance of the carbonatic phase for this metal. The residual 
phase did not show concentrations above the detection limits of the method.

$\mathrm{Zn}$ also showed a different behaviour between the stations located in the rivers mouth and the other compartments. As well as $\mathrm{Pb}$, the percentage of the carbonatic phase showed direct bonding with the total concentrations of $\mathrm{Zn}$. Both metals presented higher affinity with this phase in the urban dust and in the lagoon bottom sediments. McLean and Bledsoe (1992) and Alloway (1990a) suggested that this pattern is due to the fact that $\mathrm{Zn}$, wit a $\mathrm{pH}$ closer to 7.7 , hydrolysate and is subsequently absorbed by clays, carbonates and oxides. McAlister et al. (2005) recorded the highest occurrence of the soluble phase in the water. In the present study, the soluble phase in the water was below to the detection limit, which can be attributed to this metal easy and quickly to adhere to many organic linked, mainly in the presence of electron donators such as nitrogen and surphur (G.A. Quináglia, unpublished data).

$\mathrm{Cr}$ and mainly $\mathrm{Ni}$ showed significant percentages of the residual phase, which can be the reason for few variation in the other phases. The same pattern was verified by McAlister et al. (2005). Morillo et al. (2004) recorded the highest percentage of the residual phase in the results of both metals. This result is similar to the one of the present study, suggesting the great linking of both metals with the sediment.

In the mobile phases, the organic phase predominated in the case of Ni. Alloway (1990a) suggests that, in aerobic conditions and $\mathrm{pH}$ lower than 9, the Ni complexation with hydroxide, carbonates, surphur and organic matrices and in reduced environments forms insoluble surphur. The oxidable phase interchanged with the reductive phase for $\mathrm{Cr}$. The soluble and the carbonatic phases were below to the detected limit for both elements.

The pattern of the selective extraction for $\mathrm{Ni}$ and $\mathrm{Cr}$ did not show any differentiated pattern among the three compartments, despite the extremely differentiated environmental conditions (Fig. 4). On the other hand, the high percentage of the residual phase, mainly of $\mathrm{Ni}$, can decrease the differences among the referring percentages to each phase. Benjamin and Leckie (1981) suggested that the heavy metal partition pattern is also influenced by the total concentration. According to these authors, even the metals are absorbed by different degrees of affinity and it can occur the competition for the sites of the oxides absorption, mainly when the cations are in low concentrations, as in the case of the present study.

In a general way, the environmental differences among the compartments studied in this research showed the high influence on the partition of $\mathrm{Cu}$ and $\mathrm{Pb}$. In these particular cases, the organic phase was more influent. However, in the case of $\mathrm{Cr}$ and $\mathrm{Ni}$, it was not observed a differentiated pattern among the compartments, suggesting the highest stability of the composites formed with these metals. The great participation of the residual phase can also be responsible for the homogeneity in the dynamics of the partition of these metals (Fig. 4).

Heavy metals did not present concentrations above the detection limit, in the soluble phase in the water, suggesting that they were not bioavailable. However, the metals presented the highest percentage in the potentially mobile phase. Considering the dynamic character of the aquatic environments, the fluctuation of $\mathrm{pH}$, organic matter concentrations and $\mathrm{Eh}$ in the sediments and in the interstitial water, resulting from the natural or anthropogenic processes such as dredging or bioturbation, can cause remobilization of these metals (Acevedo-Figueiroa et al. 2006). As these characteristics are subject to natural fluctuations that result from annual climatic variations, a seasonal study should be carried out in the area, in order to get a better understanding of the geochemical cycle in this ecosystem.

\section{CONCLUSIONS}

The Rodrigo de Freitas lagoon is considered one of the most polluted coastal lagoons in Rio de Janeiro State/ SE-Brazil. The presence of $\mathrm{Cu}, \mathrm{Pb}, \mathrm{Zn}, \mathrm{Cr}$ and $\mathrm{Ni}$ in the bottom sediments of the lagoon was mostly due to anthropogenic sources, such as sanitary waste and urban dust. High concentrations of heavy metals in the urban runoff sediments suggested that this compartment can be considered an important sources of heavy metal to the lagoon, mainly $\mathrm{Pb}$ and $\mathrm{Zn}$.

The highest concentrations of $\mathrm{Cu}$ in the bottom sediments of the lagoon, highlight the capacity of the sediments in estuarine environments to concentrate pollu- 

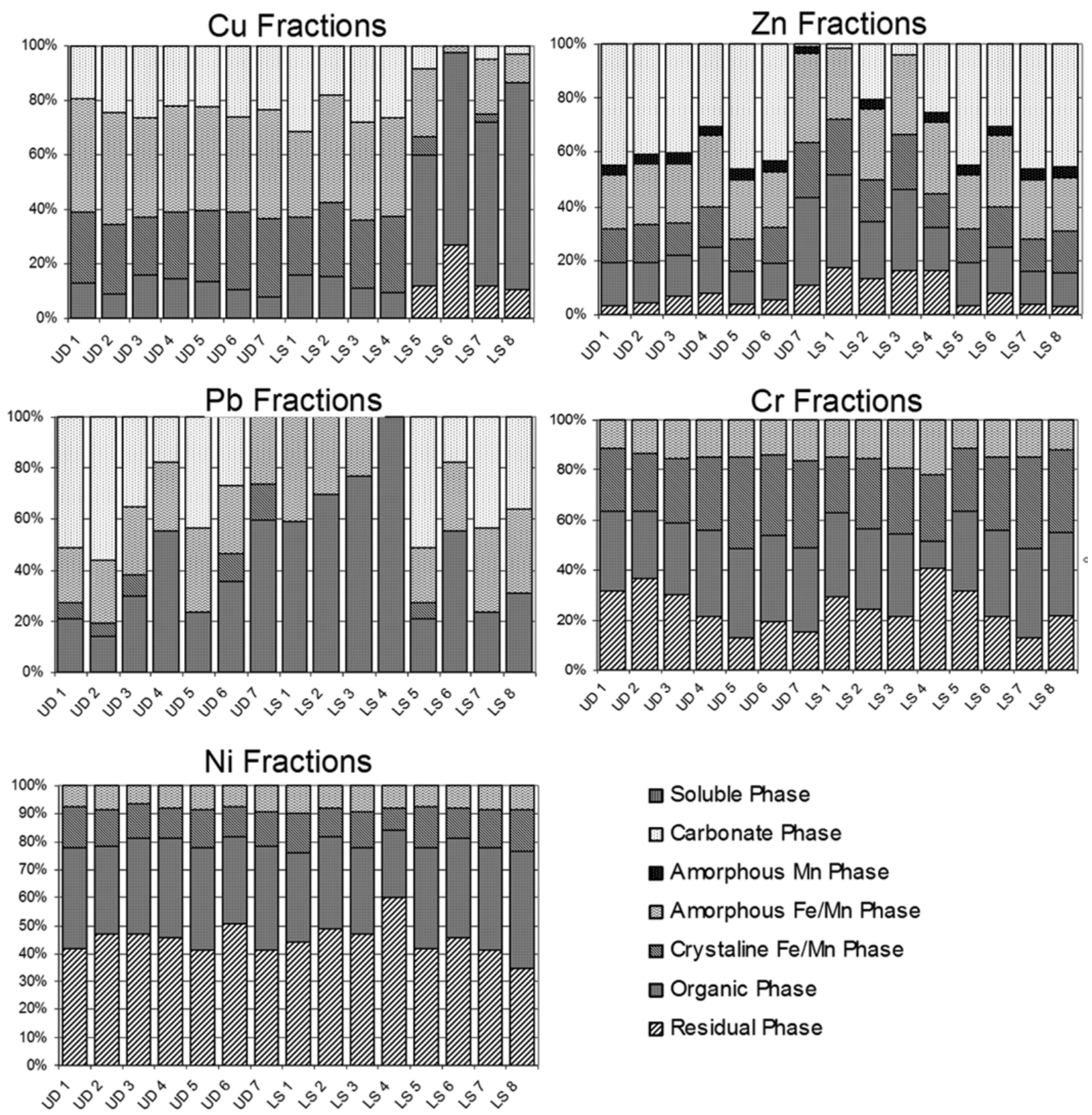

\author{
$\square$ Soluble Phase \\ $\square$ Carbonate Phase \\ - Amorphous Mn Phase \\ Amorphous $\mathrm{Fe} / \mathrm{Mn}$ Phase \\ $\square$ Crystaline Fe/Mn Phase \\ $\square$ Organic Phase \\ ఐ Residual Phase
}

Fig. 4 - Heavy metal fraccionament during the $2^{\text {nd }}$ and $3^{\text {rd }}$ campaigns.

tants, mainly contaminants with high affinity with organic matter.

The low concentrations of $\mathrm{Pb}$ in the residual phases suggested that the anthropogenic sources predominate in the study area.

The analyses had not identified concentrations of heavy metals in the soluble phase, which suggests that the heavy metals are not bioavailable for the organisms.
On the others hand, the potentially bioavailable phases were present in all the heavy metals chemical partition, suggesting a potential remobilization in the case of physical-chemical fluctuations due to several processes, such as the opening of the Jardin de Alah canal, with the increase in the water exchange between the lagoon and the sea, or eventually the dredging of the bottom sediments of the lagoon. Studies involving bio- 
indicators are necessary to evaluate the potential influence of heavy metals to living organisms.

\section{ACKNOWLEDGMENTS}

Funding for this project was provided by Coordenação de Aperfeiçoamento de Pessoal de Nível Superior (CAPES) and a research Grant from Conselho Nacional de Desenvolvimento Científico e Tecnológico (CNPq). The authors are also indebted with the staff from Queen's University (Belfast) and Universidade Federal Fluminense.

\section{RESUMO}

A urbanização acelerada, sem planejamento, resultou em uma série de problemas à zona costeira do Rio de Janeiro, especialmente em áreas como a Lagoa Rodrigo de Freitas, a qual recebe uma grande descarga de esgoto não tratado todos os dias. No intuito de avaliar a natureza, as fontes potenciais e a extensão da poluição por metais pesados na lagoa, sedimentos das ruas do entorno, das entradas do principal canal de drenagem e de superfície de fundo foram coletados. As análises se deram através de um método modificado de extração sequencial, com o objetivo de estudar o fracionamento geoquímico e a biodisponibilidade de $\mathrm{Zn}, \mathrm{Cu}, \mathrm{Cr}$, $\mathrm{Ni}$ e $\mathrm{Pb}$, nestes três compartimentos. $\mathrm{O}$ presente estudo verificou um aumento nas concentrações de $\mathrm{Cu}, \mathrm{Pb}$, e $\mathrm{Zn}$ no setor norte da Lagoa Rodrigo de Freitas. Apesar dos diferentes níveis de oxidação entre os sedimentos acumulados nas avenidas e no sedimento de fundo da lagoa, o fracionamento geoquímico dos metais pesados não apresentou nenhum padrão de variação, com exceção do $\mathrm{Cu}$. Não foram observadas concentrações na fase solúvel, das amostras coletadas nos sedimentos superficiais na lagoa, sugerindo a não biodisponibilidade dos metais pesados.

Palavras-chave: metais pesados, Lagoa Rodrigo de Freitas, sedimentos.

\section{REFERENCES}

Acevedo-FigueiroA D, Jimenez BD And RodriguezIERRA CJ. 2006. Trace metals in sediments of two estuarine lagoons from Puerto Rico. Environ Pol 141: 336-342.

Alastuey A, García-SÁnchez A, López F And QueROL X. 1999. Evolution of pyrite mud weathering and mobility of heavy-metals in the Guadiamar valley after the Aznalcóllar spill, south-west Spain. Sci Total Environ 242: 41-55.

AllowAy BJ. 1990a. Heavy Metals in Soils. Glasgow: Blackie and Son, p. 322-330.

Andreata JV, Marca AG, SoARes CL And SAntos RS. 1997. Distribuição mensal dos peixes mais representativos da Lagoa Rodrigo de Freitas, Rio de Janeiro, Brasil. Rev Bras Zool 14: 121-134.

BANERJEE ADK. 2003. Heavy metal levels and solid phase speciation in street dusts of Delhi, India. Environ Pol 123(1): 95-105.

Baptista Neto JA, Smith BJ And MCAlister JJ. 1999. Sedimentological evidence of human impact on a nearshore environment: Jurujuba Sound, Rio de Janeiro State, Brazil. Appl Geog 19(2): 153-177.

BAptista Neto JA, SMith BJ And McAllister JJ. 2000. Heavy metal concentrations in surface sediments in a nearshore environment, Jurujuba Sound, Southeast Brazil. Environ Pol 109(1): 1-9.

BArroso LV. 1989. Diagnóstico Ambiental para a pesca de águas interiores no Estado do Rio de Janeiro. Min Int, Inst Bras do Meio Amb Recurs Nat Renov 4: 174-180.

BASTA NT AND TABATABAI MA. 1992a. Effect of cropping systems on adsorption of metals by soils: II. Effect of pH. Soil Sci 153(3): 195-204.

BENJAMIN MM AND LECKIE JO. 1981. Multiple-site adsorption of $\mathrm{Cd}, \mathrm{Cu}, \mathrm{Zn}$ and $\mathrm{Pb}$ on amorphous iron oxyhydroxide. J Col Interf Sci 78: 209-221.

Benoit G, Nieder WC, Levandoswsky M And BresLIN VT. 1999. Sources and History of Heavy Metal Contamination and sediment deposition in Tivoli South bay, Hudson River. Estuar 22: 167-178.

BORCHARDT D AND SPERLING F. 1997. Urban stormwater discharges: ecological effects on receiving waters and consequences for technical measures. Wat Sci Tech 36: $173-178$.

BRown JN AND PEAKE BM. 2006. Sources of heavy metals and polycyclic aromatic hydrocarbons in urban stormwater runoff. Sci Total Environ 359: 145-155.

BuUrman P, Lagen BV and Velthorst EJ. 1996. Manual for soil and water analysis. Wageningen: Backhuys Publishers Leiden, 314 p.

Charlesworth S, Everett M, Mccarthy R, Odonez A AND DE Miguel E. 2003. A comparative study of heavy metal concentration and distribution in deposited street dusts in a large and a small urban area: Birming- 
ham and Coventry, West Midlands, UK. Environ Inter 29: 563-573.

Chatterjee A And BanerJee RN. 1999. Determination of lead and other metals in a residential area of greater Calcutta. Sci Total Environ 277: 175-185.

Cochran JK, Frignami M, Salamanca M, Bellucci LG AND GUERzoni S. 1998. Lead-210 as a tracer of atmospheric input of heavy metals in the northern Venice Lagoon. Mar Chem 62: 15-20.

FERGUSON JE AND KIM N. 1991. Trace elements in street and house dusts source and speciation. Sci Total Environ 100: $125-150$.

FÖRSTNER U AND WitTmanN GTW. 1983. Metal pollution in the aquatic Environment. Springer, Heidelberg, $486 \mathrm{p}$.

Gonzalez A, Moilleron R, Chebbo G and Thevenot DR. 2000. Determination of polycyclic aromatic hydrocarbons in urban runoff samples from the Le Marais experimental catchment in Paris centre. Polyc Arom Comp 20: 1-19.

Guilherme LRG AND ANDERSON SJ. 1998. Copper sorption kinecs and sorption hysteresis in two oxide-rich soils (Oxisols). In: VENNE EA (Ed), Adsorpiton of metals by geomedia: variables, mechanisms and model applications. San Diego: Academic Press, p. 209-228.

HARTER RD. 1983. Effect of soil $\mathrm{pH}$ on adsorption of lead cooper, zinc and nickel. Soil Sci Soc of Am Jour 47: 47-51.

Hoffman E, Mills G, Latimer JS And Quinn JG. 1984. Urban runoff as a source of polycyclic aromatic hydrocarbons to coastal waters. Environ Sci Tech 18: 580-587.

Imperato M, ADAMO P, NAIMOA D, ARIENZOB M, StanzioneA D And Violante P. 2003. Spatial distribution of heavy metals in urban soils of Naples city (Italy) Environ Pol 124: 247-256.

JONES K AND MCDONALD A. 1983. The efficiency of different methods of extracting lead from street dust. Environ Pol 6(2): 133-143.

LORING DH AND RANTALA RTT. 1991. Manual for the geochemical analyses of marine sediments as suspended particulate matter. Earth-Sci Rev 32: 235-238.

Manno E, VArrica D And Dongarra G. 2006. Metal distribution in road dust samples collected in an urban area close to a petrochemical plant at Gela, Sicily Atm Environ 40: 5929-5941.

Marseille F, Tiffreau C, Laboudigue A and LeCOMTE P. 2000. Impact of vegetation on the mobility and bioavailability of trace elements in a dredged sediment deposit: A greenhouse study. Agron 20: 547-556.

McAlister JJ, Smith BJ, BAptista Neto JA And SIMPSON JK. 2005. Geochemical distribution and bioavailability of heavy metals and oxalate in street sediments from Rio de Janeiro, Brazil: a preliminary investigation. Environ Geoch Heal 27: 429-441.

McAlister JJ, Smith BJ And Curran JA. 2003. The use of sequential extraction to examine iron and trace metal mobilisation and the case hardening of building sandstone: a preliminary investigation. Microchemical Jour 74: 5-18.

McCready S, Slee DJ, Birch GF and Taylor SE. 2000. The distribution of polycyclic aromatic hydrocarbons in surficial sediments of Sydney Harbour, Australia. Mar Pol Bull 40: 999-1006.

McLean JE And Bledsoe BE. 1992. Behavior of Metals in Soils. Ground Water Issue. U.S. EPA. EPA/540/S-92/ 018.

Morillo J, Usero J AND GRACIA I. 2004. Heavy metal distribution in marine sediments from the southwest coast of Spain. Chem, p. 431-442.

Mungur AS, Shutes RBE, Revitt DM And House MA. 1995. An assessment of metal removal from highway runoff by a natural wetland. Wat Sci Tech 32(3): $169-175$.

Murray KS, Rogers DT AND Kaufman MM. 2004. Heavy Metals in an Urban Watershed in Southeastern Michigan. J Environ Qual 33: 163-172.

NAGEROTTE SM AND DAY JP. 1998. Lead concentrations and isotope ratios in street dust determined by electrothermal atomic absorption spectrometry and inductively coupled plasma mass spectrometry. Analyst 123: 59-62.

NAIDU R, Bolan NS, KoOKana RS AND TILler KG. 1994. Ionic-strengh and $\mathrm{pH}$ effects on the sorption of cadmium and the surface of soils. Euro J Sci 45: 419429.

NGiAM L AND Lim P. 2001. Speciation patterns of heavy metals in tropical estuarine anoxic and oxidized sediments by different sequential extraction schemes. Sci Total Environ 275: 53-61.

Olivero J AND SOlano B. 1998. Mercury in environmental samples from a waterbody contaminated by gold mining in Colombia, South America. Sci Total Environ 217: 83-89.

Pereira E, Baptista Neto JA, Smith BJ And MCAlister JJ. 2007. The contribution of heavy metal pollution derived from highway runoff to Guanabara Bay 
sediments, Rio de Janeiro, Brazil. An Acad Bras Cienc 79: 739-750

Rosman PCC. 1990. Proposição de um canal estável para a melhoria da qualidade de água na Lagoa Rodrigo de Freitas. COPPE. Universidade Federal do Rio de Janeiro.

Ross SM (ED). 1994. Toxic Metals in soil-plant System, New York: Wiley, p. 63-152.

SANSALONE J AND GLENN D. 2002. "Accretion of pollutants in snow exposed to urbantraffic and winter storm maintenance activities. I.” J of Enviro Eng 128(2): 151166.

Shinya M, TSUCHINAGA T, KitAno M, YAmadA Y AND ISHIKAWA M. 2000. Characterization of heavy metals and polycyclic aromatic hydrocarbons in urban highway runoff. Wat Sci Tech 42: 201-208.

Soclo HH, GARrigues P AND EwAld M. 2000. Origin of polycyclic aromatic hydrocarbons (PAHs) in coastal marine sediments: case studies in Cotonou (Benin) and Aquitaine (France) areas. Mar Poll Bull 40: 387-396.

Sposito G. 1989. The chemistry of soils. New York: Oxford University Press, 277 p.
UNEP. 1995. Manual for the geochemical analyses of marine sediments as suspended particulate matter. Referencia Methods for marine Pollution Studies, n. 63.

VAnz A, Mirlean N And BAisch P. 2003. Avaliação de poluição do ar por chumbo particulado: uma abordagem geoquímica. Quim Nov 26(1): 25-29.

VON SCHIRNDING YER AND FugGLE RF. 1996. A study of the distribution of urban environmental lead levels in Cape Town, South Africa. Sci Total Environ 188: 1-8.

Walker WJ, McNutt RP ANd Maslanka CA. 1999. The potential of urban runoff to surface sediments of the Passaic River: sources and chemical characteristics. Chemosp 38: 363-377.

WARREN LA AND HAACK EA. 2001. Biogeochemical controls on metal behaviour in freshwater environments. Earth-Sci Rev 54: 261-320.

Yongming H, Peixuan D, Junji C And Posmentier E. 2006. Multivariate analysis of heavy metal contamination in urban dusts in Xian, central China. Sci Total Environ 355: 176-186. 